\title{
ANALISIS STRATEGI DAN EVALUASI KINERJA PENGENTASAN KEMISKINAN DALAM PROGRAM PEMBANGUNAN DESA PERSPEKTIF EKONOMI MIKRO ISLAM
}

\author{
Zakiyah* \\ Universitas Islam Kalimantan Muhammad Arsyad Albanjari, Banjarmasin \\ Atika Zahra Maulida \\ Institut Agama Islam Negeri Antasari, Banjarmasin
}

\begin{abstract}
The purpose of this study is for knowing the strategy of economic development in the village used in poverty reduction particularly in Nagara, Hulu Sungai Selatan, reviewed in perspective of micro Islam economic. The method of this research is qualitative research with the descriptive approach. Where data used is the primary data and secondary data.The results of this research are to improve the availability of distribution and expansion of various daily needs products such as health, food and clothing. Improved the life that is not only for the income, but also includes the addition of the provision of employment, improved the quality of education, and increased the cultural values and humanity. The expansion of economic and social to every individu and the whole nation. Rural development program understanding how to implement and empowering communities in any development activities, facilities, and infrastructures with a did the creativity trainings that aimed to ealleviate poverty.
\end{abstract}

Keywords: Development of Economy in the Village, Evaluation, Economic Islam

\begin{abstract}
Abstrak
Tujuan dilaksanakannya penelitian ini adalah untuk mengetahui strategi pembangunan perekonomian desa yang digunakan dalam pengentasan kemiskinan khususnya di kecamatan Nagara, kabupaten Hulu Sungai Selatan, ditinjau dalam perspektif ekonomi mikro Islam. Metode penelitian ini adalah penelitian kualitatif dengan pendekatan deskriptif. Dimana data yang digunakan adalah data primer dan data sekunder. Hasil dari penelitian ini adalah untuk meningkatkan ketersediaan serta perluasan distribusi berbagai macam barang kebutuhan hidup yang pokok seperti kesehatan, dan sandang pangan. Peningkatan standar hidup yang tidak hanya berupa peningkatan pendapatan, tetapi juga meliputi penambahan penyediaan lapangan kerja, perbaikan kwalitas pendidikan, serta peningkatan perhatian atas nilai-nilai kultural dan kemanusiaan. Perluasan pilihan-pilihan ekonomi dan sosial bagi setiap individu serta bangsa secara keseluruhan. Program Pembangunan Desa memahami bagaimana cara melaksanakan dan memberdayakan masyarakat dalam setiap kegiatan pembangunan, sarana dan prasarana dengan mengadakan pelatihan-pelatihan kreativitas yang bertujuan untuk mengentaskan kemiskinan.Evaluasi kinerja Program Pembangunan Perdesaan juga bisa dilakukan melalui kajian evaluatif terhadap proses hasil kerja pelaksanaan kegiatan program Pembangunan Desa.
\end{abstract}

Kata kunci : Pembangunan Perekonomian Desa, Evaluasi, Ekonomi Islam

\footnotetext{
Received: 19 Desember 2016; Accepted: 02 Januari 2017; Published: 12 Januari 2017

*Korespondensi: Program Studi Ekonomi Syariah, Fakultas Studi Islam, Universitas Islam Kalimantan Muhammad Arsyad Albanjari,Jl. Adhiyaksa No. 2 Kayu Tangi Banjarmasin.

Email: kikiayoenani@yahoo.com
} 


\section{PENDAHULUAN}

Indonesia merupakan sebuah negara yang mempunyai kekayaan terbanyak, namun memiliki persoalan kemiskinan dan pengangguran yang besar pula. BAPPENAS (1998) juga mengatakan "Upaya menanggulangi kemiskinan dilakukan proses penguat penduduk miskin, yang mencakup lima aspek yaitu, pengembangan sumberdaya manusia, penyedian modal kerja, penciptaan peluang dan kesempatan berusaha, pengembangan kelembagaan penduduk miskin, dan penciptaan sistem pelayanan kepada penduduk miskin yang sederhana dan efisien. Melalui jalur pendekatan tersebut, penduduk miskin diharapkan mampu, dengan kekuatan sendiri, menanggulangi kemiskinannya serta meningkatkan kesejahteraannya secara memadai dan berkelanjutan”.

Angga Harahap, (2010). Tesis yang berjudul: Partisipasi Masyarakat dalam Program Nasional Pemberdayaan Masyarakat (PNPM) Mandiri Perdesaan (Studi Deskriptif di kelurahan Aek Simotung, Kecamatan Saipar Dolok Hole, Kabupaten Tapanuli Selatan, Sumatera Utara), ia menyimpulkan bahwa: (1) Pemberdayaan masyarakat merupakan salah satu upaya untuk meningkatkan kesejahteraan masyarakat. Isu-isu kemiskinan pun senantiasa cocok diselesaikan akar masalahnya melalui pendekatan pemberdayaan masyarakat. Oleh kaerena itu, PNPM Mandiri perdesaan hadir untuk meningkatkan kesejahteraan dan kesempatan kerja masyarakat miskin secara mandiri sebagai priotas mendesak, khususnya terhadap masyarakat perdesaan. (2) PNPM-MD sebagai program penanggulangan kemiskinan di pedesaan lebih mengutamakan pada peningkatan harkat dan martabat manusia seutuhnya dengan mendudukkan masyarakat sebagai pelaku utamanya melalui partisipasi aktif.

Samuda Hulu Sungai Selatan mempunyai beberapa daerah tertinggal di perdesaannya adalah salah satunya kecamatan Samuda dan kecamatan Nagara. untuk mengatasi kemiskinan pada desa tersebut maka pemerintah Kab Hulu Sungai Selatan mencanangkan untuk program Pembangunan Desa masuk pada daerah tersebut dengan tujuan untuk mensejahterakan perekonomian desa. Salah satu langkah awal untuk memerangi kemiskinan pada daerah tersebut maka pemerintah memberikan dana APBD tersebut melalui program Pembangunan desa 
BUMDES untuk pembangunan perekonomian kerakyatan dan sejahtera. Adapun keadaan desa tersebut masih belum berkembang dalam perekonomiannya, maka dari itu pihak pemerintah memberikan sebuah pelatihan ketrampilan, pelatihan kesehatan, wirausaha dan lain-lain.

Tujuan diadakan program tersebut adalah untuk memberi ketrampilan, dan kerajinan dalam membentuk perekonomian perdesaan. Di daerah tersebut masih sulit pembangunan sarana dan prasarana pembangunan desa. Di daerah Samuda perekonomiannya masih taraf rendah dalam penghasilan penduduknya, rata-rata pekerjaan masyarakatnya adalah bertani, beternak, dan ada juga yang menjadi buruh di daerah berkembang. Oleh karena itu masih banyak masyarakat yang masih rendah tingkat pendidikan, ilmu pengetahuan, dan keterampilan. Akibat dari tertinggalnya perekonomian perdesaan maka pemerintah Kab Hulu Sungai Selatan mengadakan pelatihan, dengan tujuan membentuk karakter setiap pemuda dalam membangun perekonomia desa. Di daerah tersebut masih kurang banyak fasilitas dalam memenuhi kebutuhan masyarakat.

Melihat besarnya peranan pembangunan desa dalam pengentasan kemisikinan di Indonesia, peneliti ingin mengetahui strategi pembangunan perekonomian desa yang digunakan dalam pengentasan kemiskinan khususnya di kecamatan Nagara, kabupaten Hulu Sungai Selatan, ditinjau dalam perspektif ekonomi mikro Islam. Oleh karena itu, diperlukan suatu penelitian dengan pendekatan pembangunan desa agar permasalahan digali dan dipecahkan oleh pihak Pemerintah desa itu sendiri sehingga diharapkan dapat meningkatkan kapasitas dan melakukan pembelajaran bersama antara pihak peneliti dan pihak yang diteliti.

Berdasarkan latar belakang masalah, maka rumusan masalahnya adalah sebagai berikut: 1) Bagaimana strategi dan kinerja pelaksanaan pembangunan perekonomian desa dalam perspektif ekonomi islam ? 2) Bagaimana hasil evaluasi kinerja Pembangunan Desa di daerah Nagara ditinjau dari ekonomi islam? 


\section{METODE PENELITIAN}

Objek penelitian ini dilaksanakan di desa Samuda Hulu Sungai Selatan yang berlokasi di Samuda, Kecamatan Nagara Selatan karena desa ini merupakan salah satu desa yang pembangunan perekonomiannya kurang berkembang dan masyarakat dengan perekonomian rendah. Penelitian ini menggunakan deskriptif kualitatif untuk mengetahui kinerja program pembangunan perdesaan di desa Samuda Kec Nagara. Jenis penelitian diklasifikasikan pada jenis penelitian deskriftif kualitatif. Moh Nadzir (1999) setiap kegiatan dimulai dari perencanaan, pengaturan, pelaksanaan, pengamatan, serta hasil penelitian sedapat mungkin melibatkan pihak yang diteliti.

Sumber data primer dalam penelitian ini adalah hasil wawancara yang dilakukan peneliti terhadap AR, YD, AT, HMN, dan ILH warga desa Samuda. Data primer yang digunakan oleh peneliti adalah melalui wawancara. Data sekunder didapat dari buku-buku, jurnal ilmiah, artikel-artikel dan lain-lain.

Pengumpulan data penelitian ini menggunakan metode wawancara, kuisioner, observasi, serta studi kepustakaan. Hasil penelitian di analisis dengan menggunakan pola pikir induktif yaitu mengemukakan fakta atau kenyataan bersifat khusus dari hasil penelitian perkembangan perekonomian dalam pembangunan perekonomian sesuai pandangan Islam, lalu di analisis menggunakan teori-teori tersebut sehingga pada akhirnya dapat ditarik suatu kesimpulan.

Pengujian data merupakan upaya untuk memperoleh arti dan makna yang lebih mendalam dan luas terhadap hasil penelitian yang dilakukan. Interpretasi data dilakukan dengan menggunakan metode analisis deskriptif. Pembahasan hasil penelitian dilakukan dengan cara meninjau hasil penelitian secara kritis dengan teori yang relevan dan informasi akurat yang diperoleh dari lapangan. 


\section{HASIL DAN PEMBAHASAN}

\section{Strategi Pembangunan Perekonomian Desa}

Pembangunan ekonomi adalah usaha-usaha untuk meningkatkan taraf hidup suatu bangsa yang sering kali diukur dengan tinggi rendahnya pendapatan rill per kapita. Strategi pembangunan ekonomi desa untuk menaikkan pendapatan nasional rill juga untuk meningkatkan produktifitas. Tingkat output pada suatu saat tertentu ditentukan oleh tersedianya atau digunakannya baik sumber daya alam maupun sumber daya manusia, tingkat teknologi, keadaan pasar dan kerangka kehidupan ekonomi (sistem perekonomian) serta sikap dari output itu sendiri. Ada faktor-faktor lain yang berpengaruh terhadap penentuan tinggi rendahnya pendapatan nasional. Faktor-faktor ini berhubungan satu sama lain. Hubungan ini tidak saja hanya terjadi pada suatu saat tetapi juga untuk suatu jangka waktu tertentu. Hasil wawancara dengan Bapak AMD, dimana proses pembangunan perekonomian tersebut memiliki 3 tujuan yakni sebagai berikut:

a) Peningkatan ketersediaan serta perluasan distribusi berbagai macam barang kebutuhan hidup yang pokok seperti kesehatan, dan sandang pangan.

b) Peningkatan standart hidup yang tidak hanya berupa peningkatan pendapatan, tetapi juga meliputi penambahan penyediaan lapangan kerja, perbaikan kwalitas pendidikan, serta peningkatan perhatian atas nilai-nilai kultural dan kemanusiaan.

c) Perluasan pilihan-pilihan ekonomis dan sosial bagi setiap individu serta bangsa secara keseluruhan.

Menurut wawancara (Ketua Pemuda bapak GST) Pembangunan perekonomian di desa Samuda kurang maksimal karena kehidupan perekonomian masih kurang baik, baik dari segi perluasan distribusinya, pendapatan, lapangan pekerjaan, pendidikan serta perluasan ekonomi dan sosialnya. Peningkatan ketersediaan serta perluasan distribusi di desa Samuda kurang terpenuhi baik dari kesehatan dan sandang pangannya, karena kurangnya pengawasan pihak pemerintah terhadap kebutuhan masyarakat. Pemerintah melakukan strategi pembangunan perekonomian desa sebagai berikut : 
Tahapan persiapan sosialisasi pembangunan desa.

Dalam pelaksanaan program pembangunan desa pihak pemerintah menentukan suatu kebijakan dalam pembangunan desa yang perekonomian desanya masih tertinggal dengan tujuan untuk membangun sarana dan prasarana desa dan meningkatkan perekonomian desa. Dalam pelaksanaan kegiatan program pembangunan desa pihak pemerintah kecamatan Nagara memanggil tokoh-tokoh desa yang terdiri dari kepala desa, perangkat desa, kepala dukuh tiap-tiap desa dan tokoh-tokoh masyarakat kemudian dilaksanakan sosialisasi program pembangunan desa yang diselenggarakan di kantor Kecamatan di fasilitasi ruang pelaksanaan sosialisasi. Menurut bapak EK ”...Tujuan program Pembangunan desa masuk ke desa yang tertinggal untuk pembangunan sarana dan prasarana dalam memudahkan akses dalam kegiatan perekonomian desa, tujuan kegiatan kualitas ekonomi antara lain untuk pengembangan perekonomian desa. Dengan diadakannya program pembangunan masyarakat Kec Nagara sangat menerima sekali program-program apa saja yang akan di laksanakan di dusun ini dan sebagai masyarakat desa Samuda bisa menjalakan program-program yang di berikan oleh pihak pemerintah.”

Partisipasi masyarakat dalam program pembangunan pedesaan

Dalam kegiatan pembangunan perdesaan masyarakat ikut partisipasi dalam musyawarah kerja penyusunan program kerja pembangunan desa, partisipasi tenaga dalam pembangunan sarana dan prasarana, partisipasi masyarakat kelompok dan partisipasi dalam pengawasan dan pelaksanaan kegiatan pembangunan desa. “ Menurut Bapak PNR, dalam kegiatan pendampingan pelaksanaan kegiatan pembangunan desa, pihak pemerintah dan masyarakat mendampingi setiap kegiatan program pelaksanaan penyusunan program, musyawarah penentuan program, dan penentuan swadaya dalam penyusunan program desa yang dilaksanakan di setiap desa. Biasanya pihak pemerintah mengawasi dan mendampingi selama kegiatan berlangsung, adapun dalam kegiatan apabila ada kendala maka kendala tersebut biasanya di musyawarahkan bersama dengan pihak penanggung jawab kegiatan desa dan pihak masyarakat desa. Jadi setiap pelaksanaan kegiatan pembangunan desa masyarakat ikut serta 
dalam pelaksanaan maupun ikut serta dalam pembangunan kegiatan desa biasanya masyarakat hanya bisa ikut partisipasi dengan tenaga, uang, pikiran maupun bahan material yang di berikan dalam pembangunan.

\section{Karakteristik Ekonomi Mikro Perdesaan}

Keadaan ekonomi di pedesaan secara garis besar dapat dirumuskan program dan kebijakan-kebijakannya yang efektif untuk memerangi sumber-sumber masalah perekonomian, diperlukan pengetahuan yang lebih mendalam mengenai siapa yang termasuk dalam objek permasalahan ekonomi, dalam hal ini karakteristikkarakteristik perekonomian pedesaan menjadi sorotan, adapun karakteristikkarakteristik tersebut yakni kemiskinan yang meluas, pendapatan yang rendah, standar hidup yang buruk, meningkatnya kemiskinan, minimnya tingkat pendidikan, fasilitas kesehatan dan kurangnya lapangan perkerjaan. Menurut Todaro Michale (2003) oleh karena itu, dengan karakteristik-karakteristik tersebut dapat di atasi dengan strategi pembangunan perekonomian yang tepat untuk menanggulangi kemiskinan, pengangguran dan permasalahan ekonomi yang terjadi dipedesaan.

Menurut hasil wawancara dengan Bapak ABD (2015) “di desa Samuda ini tidak hanya memiliki satu pekerjaan demi mencukupi kebutuhan keluarganya, selain menjadi petani bapak ABD juga menjadi buruh bangunan, guru ngaji serta takmir masjid. Untuk memenuhi kebutuhan mereka istri dari bapak ABD juga bekerja sebagai tukang jahit.”

\section{Tahap Pelaksanaan kegiatan Pembangunan Perdesaan}

Unit Pelaksana kegiatan adalah promotor pelaksana kegiatan pembangunan desa secara Mandiri. adanya UPK kecamatan ini bertujuan untuk mengawasi dan mengontrol setiap kegiatan pembangunan desa di Kecamatan Nagara Kab Hulu Sungai Selatan. Tugas UPK adalah merencanakan pelaksanaan kegiatan pembangunan desa dan perkembangan desa, adapun kegiatan yang sudah direncanakan di prioritaskan dalam pengentasan kemiskinan di desa yang 
tertinggal berdasarkan kegiatan program kerja yang telah di susun dan di musyawarahkan antar desa.

Setelah di pilih dan sesuai dengan urutan peringkat kerja yang telah di musyawarahkan antar desa yang di sepakati oleh pihak pemerintahan kecamatan desa dengan di dampingi staf mendagri Kabupaten dalam penentuan program pembangunan desa dan pengembangan perekonomian desa melalui Program Pembangunan Perdesaan. Sebelum dilaksanakan program Pembangunan Mandiri desa di bentukalah Tim Pelaksana Kegiatan (TPK) tiap desa dengan tujuan untuk bisa membantu UPK dalam kegiatan pelaksanaan kinerja program PNPM Mandiri. Tugas TPK adalah menyusun rencana pembangunan, melaksanakan, mengawasi kegiatan dan melaporkan pelaksanan kegiatan baik dari segi teknis pelaksanaan, hingga laporan keuangan.

Dalam peraturan UUD tahun 2014 tentang pelaksanaan kegiatan Pembangunan Desa Yang di laksanakan dipemerintahan Presiden Jokowi dengan tujuan untuk mengentaskan kemiskinan. Proses pencairan pendanaan di cairkan melalui pihak suplier (penyedia bahan bangunan). Jadi pihak ketiga yaitu TPK tidak boleh menyediakan bahan bangunan, alat berat, dan tenaga ahli atau mempergunakan teknologi sedang atau teknologi canggih. Maka penyedian barang tersebut dilaksanakan secara lelang terbuka yang di hadiri pihak masyarakat desa, Bapak Lurah, Bapak Camat, UPK, dan TPK. Dalam pelaksanaan kegiatan Pembangunan Perdesaan dana yang di cairkan di Kec Nagara sebesar Rp 935.723.000 pada Tahun 2015/2016, Adapun rincian pelaksanaan kegiatan.

Tabel 1 Hasil Kegiatan Dana Program Pembangunan Perdesaan

\begin{tabular}{|c|c|c|c|c|}
\hline NO & $\begin{array}{l}\text { Kegiatan PNPM } \\
\text { Mandiri Perdesaan }\end{array}$ & Lokasi & $\begin{array}{c}\text { Dana } \\
\text { Pembangunan } \\
\text { Desa }\end{array}$ & $\begin{array}{c}\text { Swadaya } \\
\text { masyarakat }\end{array}$ \\
\hline 1 & $\begin{array}{l}\text { Pembangunan jalan } \\
\text { Rabat beton }\end{array}$ & $\begin{array}{l}\text { Kec Nagara } \\
\text { RT } 01\end{array}$ & 180.032 .000 & 5.230 .000 \\
\hline 2 & $\begin{array}{l}\text { Pembanguan gedung } \\
\text { paud }\end{array}$ & $\begin{array}{l}\text { Kec Nagara Rt } \\
02\end{array}$ & 50.650 .000 & 1.560 .000 \\
\hline 3 & $\begin{array}{l}\text { Pembangunan Gedung } \\
\text { Paud }\end{array}$ & $\begin{array}{l}\text { Kec Nagara Rt } \\
03\end{array}$ & 50.935 .000 & 2.450 .000 \\
\hline 4 & $\begin{array}{l}\text { Pembangunan Jalan } \\
\text { Rabat Beton }\end{array}$ & $\begin{array}{l}\text { Kec Nagara } \\
\text { Rw } 01\end{array}$ & 160.500 .000 & 4.520 .000 \\
\hline 5 & $\begin{array}{l}\text { Pembangunan Sayap } \\
\text { Jembatan/Talud }\end{array}$ & $\begin{array}{l}\text { Kec Nagara } \\
\text { Rw } 03\end{array}$ & 5.971 .000 & 0 \\
\hline
\end{tabular}




\begin{tabular}{|c|c|c|c|c|}
\hline NO & $\begin{array}{c}\text { Kegiatan PNPM } \\
\text { Mandiri Perdesaan }\end{array}$ & Lokasi & $\begin{array}{c}\text { Dana } \\
\text { Pembangunan } \\
\text { Desa }\end{array}$ & $\begin{array}{c}\text { Swadaya } \\
\text { masyarakat }\end{array}$ \\
\hline 6 & $\begin{array}{l}\text { Pembangunan Jalan } \\
\text { Rabat Beton }\end{array}$ & $\begin{array}{l}\text { Kec Nagara Rt } \\
05\end{array}$ & 140.340 .000 & 5.600 .000 \\
\hline 7 & $\begin{array}{l}\text { Pembangunan Paving } \\
\text { Balai desa }\end{array}$ & Kec Nagara 03 & 6.126 .000 & 27.000 \\
\hline 8 & $\begin{array}{l}\text { Pembangunan Gorong- } \\
\text { gorong }\end{array}$ & $\begin{array}{l}\text { Kec Nagara rw } \\
01\end{array}$ & 4.537 .500 & 0 \\
\hline 9 & $\begin{array}{l}\text { Pembangunan Jalan } \\
\text { Rabat Beton }\end{array}$ & $\begin{array}{l}\text { Kec Nagara Rt } \\
05\end{array}$ & 98.430 .000 & 3400.000 \\
\hline 10 & $\begin{array}{l}\text { Pembangunan Gedung } \\
\text { Paud }\end{array}$ & $\begin{array}{l}\text { Kec Nagara } \\
\text { Rw } 02\end{array}$ & 50.935 .000 & 2.000 .000 \\
\hline 11 & $\begin{array}{l}\text { Pembangunan Jalan } \\
\text { Rabat Beton }\end{array}$ & $\begin{array}{l}\text { Kec Nagara } \\
\text { Rt03- Rt } 04\end{array}$ & 180.650 .000 & 6.300 .000 \\
\hline 12 & $\begin{array}{l}\text { Pembangunan Talu } \\
\text { depan Halaman }\end{array}$ & $\begin{array}{l}\text { Dusun Pagar } \\
\text { Tengah }\end{array}$ & 6.616 .500 & 0 \\
\hline \multicolumn{3}{|c|}{ Jumlah } & 935.723 .000 & 31.087 .000 \\
\hline
\end{tabular}

Sumber : Data tim Pembangunan Perdesaan Kec Nagara 2015/2016

\section{Evaluasi Analisis Kinerja program Pembangunan Perdesaan}

Sebagaimana apa yang telah di paparkan pada bab hasil analisis pembahasan, penelitian penilaian strategi Kinerja Program pembangunan perdesaan. Menurut Hessel Nogi (2003) Efektifitas kinerja mereka mengacu pada subsistem formal dan terstruktur, mengukur, menilai, dan mempengaruhi sifat-sifat yang berkaitan dengan pekerjaan, perilaku dan hasil yang mempunyai fokus agar kinerja pelaksanaan program pembangunan perdesaan tersebut lebih efektif di masa yang akan datang.

Gary Dessler (1998) menjelaskan bahwa langkah-langkah dalam menilai kinerja program suatu organisasi adalah mendefinisikan pekerjaan, menilai kinerja dan memberikan umpan balik. Mendifinisikan pekerjaan maupun kinerja berarti memastikan bahwa tugas-tugas standar (panduan kerja). Menilai kinerja berarti mengukur kinerja keberhasilan program-program yang dilaksanakan.

Hal ini yang harus diperhatikan dalam perencanaan partisipasi Pembangunan Perdesaan adalah melibatkan perangkat pemerintahan desa/ kelurahan (pemerintahan desa/ kelurahan, Badan Permusyawarahan Desa/ BPD, dan Lembaga Kemasyarakatan Desa/ kelurahan) dalam memfasilitasi masyarakat. Oleh sebab itu perlu dilakukan peningkatan kapasitas kinerja perangkat pemerintah desa/ kelurahan dalam menjaring aspirasi, permasalahan dan potensi 
masyarakat secara nyata. Adapun tolak ukur evaluasi kinerja Pembangunan Perdesaan sebagai berikut:

a) Meningkatkan peranan pastisipasi masyarakat miskin dalam kegiatan pembangunan desa dan perkembangan ekonomi desa.

b) Penurunan jumlah pengangguran dalam kurun waktu satu tahun pelaksanaan program Pembangunan Perdesaan.

c) Adanya peranan pemerintah dalam meningkatkan kebijakan pemerintah dalam pelaksanaan proses kegiatan Pembangunan Desa.

d) Pemerintah mempunyai segala peran dalam penentuan kebijakan selama pelaksanaan kegiatan, maupun pengawasan, dan pengontrolan pembacaan laporan hasil akhir pelaksanaan kegiatan.

e) Meningkatkan akses jalan desa agar bisa membantu perekonomi perdesaan.

f) Peningkatan pendapatan masyarakat miskin dalam kurun waktu satu tahun.

g) Adanya peraturan keuangan mikro kecil yang pro rakyat dan mudah diterapkan dalam masyarakat perdesaan.

h) Meningkatnya jumlah usaha baru dari masyarakat miskin yang dapat di kembangkan melalui program Pembangunan Desa.

i) Peningkatkan tenaga kerja yang dilibatkan dalam usaha baru dari masyarakat miskin yang dapat di kembangkan melalui program Pembangunan Desa.

j) Peningkatan produktivitas usaha baru dari masyarakat miskin yang dapat dikembangkan melalui program Pembangunan Desa.

k) Adanaya peranan pemerintah dalam faktor produksi dan pemasaran hasil produksi program Pembangunan Desa.

l) Peningkatan kemampuan masyarakat miskin dalam mengkonsumsi barang, terutama kebutuhan pangan.

m)Peningkatan supply air bersih dan penggunaan air bersih oleh masyarakat.

n) Peningkatan partisipasi anak dalam pendidikan dasar dan menengah.

o) Adanya peranan pemerintah desa dalam mengawasi dan mengontrol kesejahteraan masyarakat desa dengan melalui program Pembangunan Desa 
p) Adanya pengawasan kinerja para fasilitator, UPK, dan TPK dalam pelaksanaan kegitan Program Pembangunan Desa

\section{PENUTUP}

Berdasarkan analisis dan pembahasan mengenai pembangunan perekonomian desa dilihat dari ekonomi mikro syariah, dapat diambil kesimpulan bahwa akikat program Pembangunan Desa terjun di masyarakat desa tertinggal dengan tujuan untuk mengentaskan kemiskinan desa. Konsep Pembangunan Desa memahami cara pelaksanaannya dengan memberdayakan masyarakat dalam setiap kegiatan pembangunan, sarana dan prasarana maupun pembangunan perekonomian lewat kegiatan pembangunan sarana dan prasarana, pelatihan-pelatihan kreativitas seperti tata boga, tata rias, budidaya patin, kerajinan purun, dan lain-lain. Rangkaian konsep kegiatan Pembangunan Perdesaan terdiri dari sosialisasi, musyawarah program, pelaksanaan kegiatan dan pelatihan di Kec Nagara telah berjalan dengan baik dan lancar meskipun ada beberapa kendala-kendala yang terjadi. Adanya peranan kebijakan pemerintah yang bisa menyelesaikan masalah tersebut dengan baik. Evaluasi kinerja Program Pembangunan Perdesaan bisa dilakukan melalui kajian evaluatif terhadap proses hasil kerja pelaksanaan kegiatan program Pembangunan Desa. Hasil kinerja program Pembangunan Desa telah terlaksana dengan baik dan lancar, tetapi ada beberapa kendala dalam pelaksanaan dalam pelaksanaan program pembangunan desa dan program perekonomian desa tersebut. Tujuan adanya evaluasi kinerja ini dilakukan untuk mengetahui pelaksanaan kinerja program mana yang belum terlaksana, apa penyebab belum terlaksananya, oleh karena itu perlu adanya evaluasi kinerja untuk mengukur hasil kerja program Pembangunan Desa dalam pengentasan kemiskinan. Dari kesimpulan di atas penulis memberikan saran yang dapat diberikan penulis untuk kemajuan Indonesia terutama Desa Samuda Kec Nagara yakni: Meningkatkan sosialisasi kepada masyarakat luas mengenai masalahmasalah perkembangan perekonomian dengan tujuan untuk mewujudkan pembanguan perekonomian yang lebih baik. Meningkatkan sosialisasi kepada masyarakat desa mengenai pentingnya pendidikan, kesehatan, dan teknologi. 
Dengan dilakukannya penelitian ini diharapkan pihak pemerintah lebih memperhatikan pembangunan perekonomian di pedesaan.

\section{DAFTAR PUSTAKA}

Azizy, A.Qodri. 2004. Membangun Pondasi Ekonomi Umat; Meneropong Prospek Perkembangan Ekonomi Islam. Yogyakarta: Pelajar

An-Nabhani, Taqiyyudin. 2009. Membangun Sistem Ekonomi Alternatif Perspektif Islam. Surabaya: Risalah Gusti

Angga Harahap. Partisipasi Masyarakat dalam Program Nasional Pemberdayaan Masyarakat (PNPM) Mandiri Perdesaan (Studi Deskriptif di Kelurahan Aek Simotung, Kecamatan Saipar Dolok Hole, Kabupaten Tapanuli Selatan, Sumatera Utara). Tesis Universitas Sumatera Utara, Medan. 2010

BAPPENAS. 1998. Gerakan penanggulangan Kemiskinan: Laporan Penelitian di Daerah-daerah. Yogyakarta: Penerbit Aditya Media

Budiman, Arief. 2000. Teori Pembangunan Dunia ke Tiga. Jakarta: PT Gramedia Pustaka Utama

Chapra, M.Umer. 2000. Islam Dan Pembangunan Ekonomi. Jakarta: Gema Insani

Gary Dessler. 1998. Manejemen Sumber Daya Manusia. edisi IV. Jakarta: Prenhallindo

Herrick, Bruce. 1998. Ekonomi Pembangunan Edisi ke empat. Jakarta: Bina Aksara

Herlambang, Tedy, dkk. 2002. Ekonomi Makro. Jakarta: PT Gramedia Pustaka Utama

Jhingan. 2010. Ekonomi Pembanguan dan Perencanaan. Jakarta: Rajawali Press

Kusmuljono. 2009. Menciptakan Kesempatan Rakyat Berusaha. Bogor: IPB Press

Karim, Adiwarman. 2010. Ekonomi Mikro Islami. Jakarta: Rajawali Pers

Munir, Ruzi. 1986. Penduduk dan Pembangunan Ekonomi. Jakarta: PT Bina Aksara

Mubyarto dkk. 1992. Perekonomian Rakyat Kalimantan. Jakarta: Aditya Media

Nadzir Moh. 1999. Metode Penelitian. Jakarta: Ghalia Indonesia

Sujatmoko. 1992. Pembangunan Berkelanjutan. Jakarta: Gramedia Pustaka Utama

Suroto. 1992. Strategi Pembangunan dan Perencanaan Kesempatan Kerja. edisi kedua. Yogyakarta: Gajah Mada University Press

Soekartawi. 1996. Pembangunan Pertanian Untuk Mengentas Kemiskinan. Jakarta: UI- Press

Suryana. 2000. Ekonomi Pembanguan Problematika dan Pendekatan. Jakarta: Salemba Empat 
Sukirno, Sadono. 2007. Ekonomi Pembangunan: Proses, Masalah, dan Dasar Kebijaka. edisi kedua. Jakarta: Kencana

Todaro, Michael P. Smith, Stephen C. 2003. Pembangunan Ekonomi di Dunia Ketiga. Jakarta: Erlangga

Tambunan, Tulus Tahi Hamonangan. 2008. Pembangunan Ekonomi dan Utang Luar Negeri. Jakarta: Raja Wali Pers

Usman, Dr. Sunyoto. 1998. Pembangunan dan Pemberdayaan Masyarakat. Yogyakarta: PUSTAKA PELAJAR

Wie, Thee Kian. 1983. Pembangunan Ekonomi dan Pemerataan: Beberapa Pendekatan Alternatif. Jakarta: LP3ES

Wirosuhardjo, Kartomo, dkk. 1986. Kebijaksanaan Kependudukan dan Ketenagakerjaan di Indonesia. Jakarta: Fakultas ekonomi Universitas Indonesia

Wawancara dengan Bapak PNR di Desa Samauda Kec. Nagara, tanggal 13 November 2016 